\title{
Problems of Development in Bangladesh: Causes and Remedies
}

Taha Husain

Social Science Research Forum, Dhaka, Bangladesh

*Corresponding author: Husain T, Social Science Research Forum, Dhaka, Bangladesh, Tel: +880 2-8912280; E-mail: bdsocialsrf@gmail.com

Received date: June 10, 2017; Accepted date: July 17, 2017; Published date: July 21, 2017

Copyright: (C) 2017 Husain T. This is an open-access article distributed under the terms of the Creative Commons Attribution License, which permits unrestricted use, distribution, and reproduction in any medium, provided the original author and source are credited.

\begin{abstract}
The word development has become a blazing topic in the milieu of scholars, think tanks and civil society in Bangladesh for the last couple of years. Even some development experts claimed to modify the present development approaches in Bangladesh. The purpose of this paper is to identify the problems of the conventional development system in Bangladesh and to provide a model of development that will serve the people best. To address the aims of this study both qualitative and quantitative method is used. Where both the primary and secondary data used for this study, after analyzing the data, this paper argues that a number of flaws remain in conventional growth based development system in Bangladesh. Such as, not all growth is positive, an increase of personal income does not translate into well-being, and absence of inclusive development. In addition, the faults can eradicate by introducing freedom of choice. Because if the freedom of choice ensues then the inclusive development, human development, as well as good governance, would develop in Bangladesh.
\end{abstract}

Keywords: Development; Human development; Freedom of choice; Good governance

\section{Introduction}

The word development is much ventilated in the current era of the global economy. Where the development of a country is measured by the amount of GDP and GNP. That means the developed states must have high GDP, GNP and per capita income as well. The happiness, prosperity, and development of people measures by some numbers and statistics. To measures development with those numbers and statistics of GDP, GNP or per capita income, has some fundamental problems. Firstly, the development is seen as economic growth where all growth sees as positive. For example, the growth of tobacco product, the growth of arms and ammunition. On the contrary, household work of women or even reproductive work of women also does not count in GDP. Secondly, the income is seen as an indicator of happiness and prosperity, not as an input. Thirdly, this type of thinking overlooks the pocket poverty of a country. Fourthly, it does not represent all residents of a country. For example, in Bangladesh, the control of its $90 \%$ of GDP lies in the hand of only $8 \%-10 \%$ of its residence. Thus, the purpose of this study to explore the above-mentioned problem in the context of Bangladesh. Moreover, to propose another development approach, which contradicts with so-called growth based development and give more emphasize on inclusive development and freedom of choice.

To meet the objectives of the study a combination of both quantitative and qualitative approach used. It appeared to be the best fit as one would supplement the other for a comprehensive understanding of the problem in hand. Thus, this study conducted in mixed methodology. Mixed methods research takes advantage of using multiple ways to explore a research problem. For the quantitative approach, the data collection method followed the questionnaire survey and for the qualitative approach in-depth interviews. The respondent of the survey consists of final year or the graduate student who have a course in development studies. On the other hand, the interview taken from the Rickshaw Pullers, Slum Dwellers and Middle-Class people from the Dhaka city. The respondent selected for this study based on convenience sampling. Because the population is just too large and access to them is impossible. Despite the fact, the findings of this paper after taking consideration the concerned policy makers will be able to take more sound policy in this area.

\section{Literature Review}

While searching the discourses and vital intellectual tradition of development, we found two patterns of development discourse. The development approaches initiated during the cold war period and after cold war period. Such as Todaro [1], in his books revealed the traditional development system. Likewise, the other scholars during cold war he also took the development as the number of the gross domestic product (GDP), Gross National product (GNP) and per capita income (PCI). The amount of PCI appears as the final standard of national progress and prosperity. Many scholars like Szirmai supported this thought and opined that development denotes to the capacity of the national economy to generate and sustain an annual increase in its GNP at rates of perhaps 5 to 7 percent or more. However, few Scholars like Stiglitz et al. [2], did not agree with them. Not only Stiglitz et al. [2] but also the traditional scholars like Hicks and Streeten [3] also opposed that view. They claimed that, the scholars who contained the GDP, GNP, PCI philosophies they actually judged development by looking at some statics. They try to calculate the economic activity not merely the development. Because development is a broad term, it cannot confine into some numbers and statistics.

Later when the cold war terminated, the notion of the welfare state had become popular in this world. Throughout the world, liberalization of economic activities, free trade area, open market and the tariff barrier free economy came in focus. Gradually the earlier notion development changed, instead included new and creative thoughts of development. The scholars like David [4], Haq [5], Sen [6] and Van der Gaag [7] brings the new idea of development. They 
included better nutrition and health services, greater access to knowledge, more secure livelihoods, better working conditions, security against crime and physical violence, satisfying leisure hours, and a sense of participating in the economic, cultural and political activities of their communities as the indicator of development. So during this period most of the prominent scholars focused on Human Development (HD).

All of the research conducted in abroad, in Bangladesh, the research on this field is absence. Thus, this paper will meet the research gap and give more emphasis on not only human development but also inclusive development and development viewed as freedom of choice.

\section{Operational Definition}

\section{Development}

Generally, development is, as we mention in the previous part, thought as economic growth expressed in total numbers and statistics [8]. The well-being of people or the development is measured in monetary terms [9]. Where country's development measured as GDP, GNP and per capita income [10]. The GDP is the sum of all goods and services produced within a country's territory, and GNP is the total production of all its citizens wherever they live [11-14]. However, this paper will present development as inclusive development that will more comprehensive, participatory, innate, and lucid. Thus, this connotation of development will deliver people's freedom choice.

\section{Human development}

The idea of Human Development (HD), as we discussed in the literature review, introduced in United Nations by Mahbub-ul-Haq [5]. Theorized and operationalized by Amartya Sen $[15,16]$. Moreover, it gained popularity through the initiation of Human Development Index (HDI) by United Nation since 1990 [17]. It aimed at challenging the traditional growth-based economy and the development policies dictated by Washington consensus in the 1980s [18]. Generally, human development composed of indicators for income, health, and education [19]. The human development for this paper is the people's freedom of choice along with the income, health, and education.

\section{Freedom of choice}

The term freedom of choice is not well-defined in an academic area [20]. It has diverse meaning to dissimilar scholars in a different society [21]. Economist Amartya Sen stated that enhancing our freedom should the object and means to achieving development and thus welfare $[6,22]$. Thus, there are varied purposes of freedom of choice; instrumental versus intrinsic, axiomatic [23,24]. However, for the Pattanaik and $\mathrm{Xu}$ [25], freedom of choice more indicates to the opportunity for preference. In spite of those varieties, this paper will look forward intrinsic meaning of freedom of choice. Power to take a decision, an authority to improve inclusiveness and set up pluralism in Bangladesh.

\section{Conceptual framework}

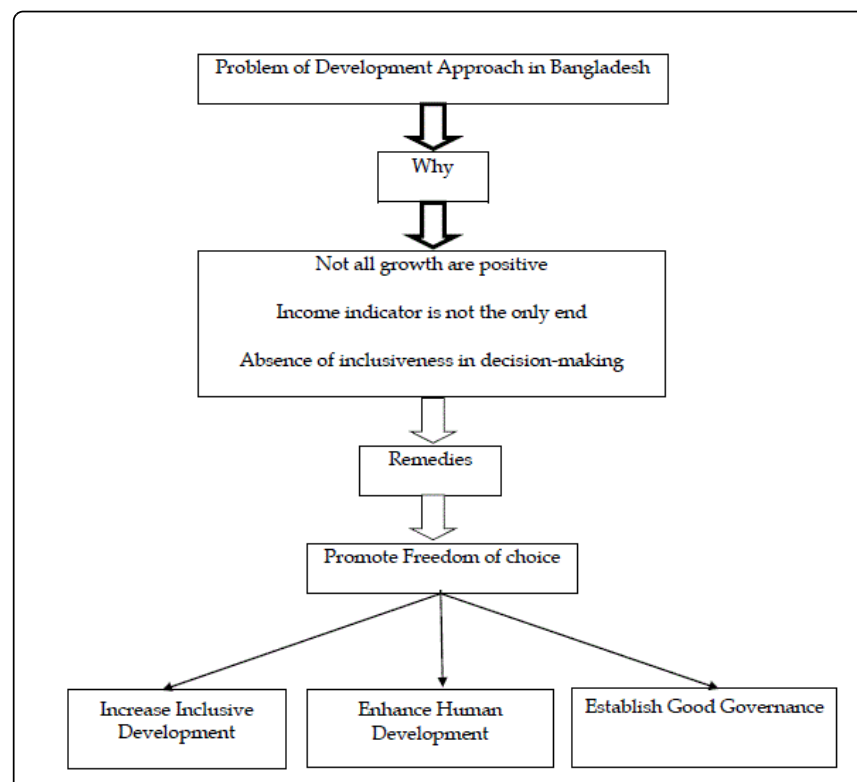

Figure 1: Conceptual framework of causes and remedies on the problems of development approach in Bangladesh.

This conceptual framework is hypothetical; this is not a clear-cut description rather it guides the discussion of this paper (Figure 1).

\section{Problems of Development in Bangladesh}

\section{Not all growth is positive}

Bangladesh follows the traditional ways of Development. That means the development of economic growth or monetary development, where all growth considers positive. The problem in this view is that it never differentiates the economic growth from the negative and positive point of view. Rather it takes a close look at some number and statistics of GDP and GNP. If the GDP and GNP rate is high then it proved that the country's development is going well. For example, the Asian Development Bank's chief economist Shang-Jin Wei opined that high economic growth in Bangladesh indicates the country's continuing improvements in political and business environment ${ }^{1}$. That means they assess the final happiness, prosperity, definitive satisfaction, thriving, even sadness and poverty, of the people based on those statistics. For instances, the planning ministry of Bangladesh claimed that in the fiscal year of 2016/17 the country's GDP growth would hit a record 7.24 percent. The National Economic Council also remarked that this would beat all previous record of development in Bangladesh [26].

However, the significant issue of such speculation is that the GDP of Bangladesh would even hike up for the money or income from negative sources. Such as pay of tobacco (cocaine, heroin, Dauphine, ganja) pay of destructive objects (arms ammunitions, others military equipment, explosive harmful to the human body). Interestingly in

$1 \quad$ https://www.scribd.com/document/313164537/High-Economic-Growth-Awaits-BangladeshSaha\%20\%20S\%20(2014)\%20\%20High \%20Economic\%20Growth\%20Awaits\%20Bangladesh.\%20The\%20Daily\%20Star.:\%20http:/www.thedailystar.net/high-economicgrowth-awaits-bangladesh-46056 
Bangladesh Hakimpuri Jorda (Type of Tobacco) owner, Kaush Mia came to the limelight of the country during the last three years as a top taxpayer [27]. Besides there are ten to twelve tobacco companies with thousands of factories in Bangladesh also contributes to this GDP [28]. Everyone knows how much devastated these are. With blind eyes, we accept those things as an indicator of development. Besides the abovementioned indicators, the income indicator includes the cost of leisure and relaxation (TV, Cinema, Air condition, tourism, mobile, laptop). Yet valuable work at home family unit work of poor women, or as volunteer work in families such as rearing and raising children, serving family will not quantify as development because these sorts of work do not create cash.

\section{Income indicator is not the only ends}

Another problem of conventional understanding of the term development is it eventually measures the prosperity, happiness, success, joy and wellbeing looking at income and salary. That means more income rate perceives as more happiness or better salary sees as more satisfaction. However, income does not translate automatically into happiness and prosperity [29]. Rather income is input only, not the ends. For instance, increase in personal income in Bangladesh does not always prove a woman's access to resources or her personal consumption. So thus, this growth-based development does not take into account non-monetary deprivation of women. Besides, it is not always true that if my salary is double-digit and your one is four digits so that I am less happy or less cheerful than you are. For example, the rickshaw pullers often earn five to seven hundred BDT on a day but said they are happy with these earnings [30]. On the contrary, some diagnosis center owner in their interview claimed that after earning five to ten thousand a day they are not happy and satisfied [31]. These two groups of people live in the same city with different occupations; their wage of earning is different and has a huge discrepancy. Despite the fact, the happiness varies. Thus, the idea of more income bring more happiness is lame. Rather happiness, prosperity, and well-being depend on the freedom of choice.

\section{Absence of inclusiveness in decision making}

This type of conventional growth-based development does not represent all residents of a country. If we look at the concept behind large donor-funded or government subsidized undertakings in this country, such as projects of large bridges, power plants, and flyover. In several occasions, it is found that the government takes the decision to build it not knowing or caring the public demand. Besides those large and expensive development constructions, there are thousands of people living in the slum. Over $1.5 \%$ people of the country live in slums across the country, $2.23 \mathrm{~m}$ people live in slums [32]. One can see both the largest flyover and slums as well at Dhaka city. For example, $54.9 \%$ slums located at Dhaka city as well as $90 \%$ fly over at this city [33]. These scenarios revealed the two opposite scenario of a country. That means the growth based conventional development overlooks the pocket poverty of a country.

The scholars and economist like Dr. Mohammad Younus opined on several occasions that in Bangladesh $90 \%$ of its GDP controlled by merely $8 \%-10 \%$ of its people [34]. Thus, it creates social imbalance and hardship, in Bangladesh, a clear social deviation was found. For example, the country's 160 million people are divided into two segments. One is a small number of extremely powerful people, no more than one million and another is extremely powerless people comprises 159 million. This situation is better explained by an ordinary slum dweller, who opined that the people of this country have one foot on the chunk of ice and another foot on the burning coal. No one concentrate on the plight of the poor people. They are the exploited ones [35].

According to the latest survey now, the Gross Domestic Product per capita in Bangladesh is 972.88 US dollars [36]. This amount is increasing day by day. This national income trickles down for those $8 \%$ individuals of this country. For example, Business tycoon Salman F Rahman [37] has been placed on the billionaire's list of Hurun Global, with assets worth about $\$ 1.3$ Billion [37]. Therefore, the per capita income is increasing for the man like these. Thus, the indicator does not even change the lifestyle of rest of the populace of Bangladesh. However, a nation's GDP of some number of dollars does not generally say anything clear in regards to any of the citizens of that country. Therefore, the number and statistic of measurement do not automatically translate into well-being because those total figures do not explain the equal wealth distribution.

\section{Remedies: Freedom of Choice}

\section{Inclusive development}

In Bangladesh, the demand for inclusive development is well accepted. The survey of this study found that among the respondent $70 \%$ in favor of inclusive development. Rest of the $30 \%$ respondents who opposed the inclusive development mentioned three reasons for opposing it. First, $61 \%$ of the respondents who opposed the inclusive development believe the mass people are uneducated; they do not have enough idea about the development. $27 \%$ of the respondent thought that if every time the government takes the decision from the populace, then the opposition political parties will take this chance to jeopardize the development project. On the other hand, 9\% of them thought that the inclusive development will increase bureaucratic complexity in Bangladesh. Rest of the respondent mention other difficulties like procrastination of development and the opinion of a member of parliament is the opinion of people itself.

From the above-mentioned survey result, two things are clear; the majority of the people in Bangladesh are in favor of inclusive development, and the people who opposed it they have lack knowledge about inclusive development. Generally, the word inclusive means covering every one of a certain place. In addition, literally, it denotes including all the services, facilities, or items normally required (Merriam-Webster Dictionary). While there is no agreed and common definition of inclusive development available in the academic area [38]. The term understood by some scholar as the development combined with equal opportunities. That means the idea of inclusive development consists of economic, monetary, social and institutional dimensions and entails a process of shared prosperity [39].

The strength of this inclusive development distinguishes it from other development thoughts. Reasonably, it is pro-poor and comprehensive development. It is pro-poor because it reduces income poverty, for example, it removes the lower-income inequality and the increment of income accrues disproportionately [38]. Thus, inclusive development brings a better environment to human beings and conveys better system for individuals. However, it also ensures the flexibility in decision-making that means the freedom of choice. The inclusive development and freedom of choice are mutually reinforcing one. Because freedom of choice in decision-making also guarantees equal opportunities, in spite of the people's power and background. 
Therefore, a multi-dimensional process facilitates the active contribution of every member of the society in all aspects of life. Including the civic, social, economic, political and decision-making, that is why if Bangladesh takes this strategy then the development will benefit the whole community regardless of gender and class. In addition, ensures inclusion, equal opportunity and enhances the ability of all members of the society.

\section{Human development}

Human development is multidimensional [40]. However, the existing human development indicators do not meet the growing challenges of gender disparity. For instance, a report in 1975 by ILO had found that while women and girls make ups almost $50 \%$ of the total populace, $33 \%$ of official labor force, and covers $66 \%$ of working hours, but they receive just one-tenth of the world's pay. This was during the cold war when the golden age of growth-based economy ruled the world. Almost a quarter century later, United Nation's UNDP Human Development Report 1994 found that, despite advances in labor force participation, education and health; women still constitute $66 \%$ of the world's illiterates, hold less than half of the employments available on the market, and paid half as much as men for work of equal esteem [41]. Bangladesh needs such human development that focuses on inclusiveness. While current human development milieu the family context is absence. Nevertheless, the linkages between family and human development are substantial. Because the family factors such as, daycare, peer groups, school, social networks, the place of work, all of these needs to ensure human development. In addition, this decision dependent on individual's freedom of choice. If an individual is not able to uphold these issues to decision makers then how could human development possible?

\section{Good governance}

Even though the term governance is as old as humankind's history. It has become the intellectual debates among researchers when UNrelated thoughts as decolonization and human rights came in limelight after the Second World War [42]. Thus, the broad concept of governance applied in different contexts in global, national, institutional and community level [43]. Later, poor governance has leveled as the most important causes and imperative reasons of state failure and underdevelopment [44]. Kofi Anan had appropriately enunciated that good governance is perhaps the single most vital considering in eradicating poverty and advancing development. The transparency and accountability are the center components of good governance [45].

However, the inclusive development or freedom of choice has a good connection in ensuring good governance, because the inclusive development helps to maintain transparency and accountability. It acknowledges the bottom-up approach, that implies choice originate from the grassroots level. Where common populace chooses what they require and what they do not need. Therefore, in light of their choice government will take the formative tasks and developmental projects. For example in Bangladesh when the administration takes their development projects, every time, it faces common people up surging. Either that is nuclear electric power projects or metro rail ventures. For example the recent public protest against the Rampal electronic power plant of countries Bagerhat district, this development project attracting criticism in Bangladesh and abroad. Several protests have been held in Dhaka and other Bangladeshi cities. Even the protesters were showing their disapproval of a new coal-fired power plant at Rampal. They claimed that it poses threats to the nearby Sundarbans mangrove; the largest mangrove forest in the world, as well as to the health of thousands of local residents [46]. Similarly, the protest over building a new mega international airport in Arial Beel area of Munshiganj also came in the limelight because the village people took their arms to protect agricultural land [47]. Many feared displacement and expressed unwillingness to sacrifice the wetlands [48]. Thus, people revolted to protect Arial Beel. The battle highlighted that the rural-agrarian periphery would not like to be ordered by the urban political center to swallow a mega project [49]. These two examples indicate that the inclusive development or the bottom up approach is best suitable in Bangladesh. Thus, the good governance can be maintained.

Moreover, another important element of good governance is the practice of democracy and protection of human rights. Democracy is all about freedom of choice. If one wants to establish democracy (votebased system), you need to establish freedom of choice first. Between democracy and freedom of choice, a direct causal relation exists. On the other hand, the human rights encourage uniformity of people regardless of their race, color, sex and nationality. The inclusive development additionally has the same value. For example, the inclusive development gives an opportunity to decide what ones want. Human rights also contain the same value of equal opportunity for all. This is how the two ingredients', freedom of choice and inclusive development help to establish democracy and human rights, thus the good governance [50-57].

\section{Conclusion}

The development is a necessary component for the wellbeing of a country because it signifies progress and growth. The mismanagement of development approach is a major factor of why developing countries are lagging behind. As a developing country, Bangladesh also faces the same reality. The development system Bangladesh follows has some problems that increase the bureaucratic complexity as well as the people deprived of necessary services. In Bangladesh, where the money from harmful production includes in GDP and GNP but the reproductive work of women at home does not consider it, the per capita income is considered as the indication of happiness but happiness does not lie into the income only. Moreover, the major problem of this development system is the lack of inclusiveness. The decision makers have little connection to general people; rather the large development project is taken based on a decision taken by the elite society of the country for their benefit.

In concluding it can be said that, the practice of freedom of choice would be appropriate to remove the barriers to development in Bangladesh, because it can enhance the inclusive development, human development as well as the good governance in Bangladesh, based on the public perception of this study in supporting the inclusive development, further study on how to initiate the inclusive development need to conduct. Where the details direction should be portrayed so, that the policy makers can use it and imply smoothly in the respected field.

\section{References}

1. Todaro M (1997) Economic development. Longman, London.

2. Stiglitz JE, Sen A, Fitoussi JP (2009) Report by the commission on the measurement of economic performance and social progress.

3. Hicks NL, Streeten, P (1979) Indicators of development: The Search for a Basic Needs Yardstick. World Development, pp: 567-580. 
4. David MM (1979) Measuring the conditions of the world's poor-the physical quality of life index. Pergamon Press, New York.

5. Haq MU (1995) Reflections on human development. New York: Oxford University Press.

6. Sen A (1999) Development as freedom. Oxford University Press, New York.

7. Van der Gaag J (2011) The economics of human development International Conference on Early Childhood Development, Beijing.

8. Griliches Z (1990) Patent statistics as economic indicators: a survey (No. w3301). National Bureau of Economic Research.

9. Campbell A (1976) Subjective Measures of Well-Being. American Psychologist 31: p: 117.

10. Kormendi RC, Meguire, PG (1985) Macroeconomic determinants of growth: Cross-Country Evidence. Journal of Monetary Economics 16: 141-163.

11. Robinson J (1979) Aspects of development and underdevelopment. Cambridge University Press, Cambridge.

12. Streeten P (1979) Development ideas in historical perspective. In: Colloquium RC (ed.) Toward a new strategy for development. Pergamum Press, New York, pp: 21-52.

13. Hoogvelt A (1982) The third world in global development. London: Macmillan Education Ltd.

14. Callen $\mathrm{T}$ (2008) What is Gross Domestic Product? Finance and Development, pp: 48-49.

15. Sen A (2000) A decade of human development. Journal of Human Development, pp: 17-23.

16. Fukuda-Parr S (2003) The human development paradigm: Operationalizing Sen's Ideas on Capabilities. Feminist Economics 9 301-317.

17. McGillivray M (1991) The human development index: yet another redundant composite development indicator? World Development, pp: 1461-1468.

18. Gore C (2000) The rise and fall of the Washington consensus as a paradigm for developing countries. World Development, pp: 789-804.

19. Noorbakhsh F (1998) A modified human development index. World Development, pp: 517-528.

20. Klemisch-Ahlert M (1993) Freedom of choice. Social Choice and Welfare 10: 189-207.

21. Dowding K, Van Hees MA (2009) Freedom of choice. pp: 374-392.

22. Sen A (2005) Human rights and capabilities. Journal of Human Development, pp: 151-166.

23. Puppe C (1996) An axiomatic approach to "Preference for Freedom of Choice". Journal of Economic Theory, pp: 174-199.

24. Klemisch-Ahlert M (1993) Freedom of choice. A Comparison of Different Rankings of Opportunity Sets. Social Choice and Welfare, pp: 189-207.

25. Pattanaik PK, Xu Y (2000) On diversity and freedom of choice. Mathematical Social Sciences 40: 123-130.

26. The Daily Star (2017) GDP growth record 7.24pc, per capita income $\$ 1,602$.

27. Karmakar S (2016) The story of being a grocery businessman's highest taxpayer. Prothom Alo.

28. LCW (2015) List of tobacco companies in Bangladesh.

29. Palley TI (2005) From keynesianism to neoliberalism: shifting paradigms in economics. Neoliberalism: A Critical Reader, pp: 20-29.

30. Mazid A (2017) Personal interview.
31. Gani O (2017) Personal interview.

32. The Dhaka Tribune (2015) Census: $2.23 \mathrm{~m}$ people live in slums. The Dhaka Tribune.

33. Islam NAQMM, Nurul Islam N (2009) Urban slums of Bangladesh. The Daily Star.

34. Yunus M (2016) 129th IOC session-keynote speech by Professor Muhammad Yunus.

35. Mia S (2017) Personal interview.

36. Trading Economics (2017) Bangladesh GDP per capita. Trading Economics.

37. Salman FR (2017) On World Billionaires' List. Dhaka Tribune.

38. Rauniyar G, Kanbur R (2010) Inclusive growth and inclusive development: a review and synthesis of Asian Development Bank Literature. Journal of the Asia Pacific Economy 15: 455-469.

39. Conceição P, Gibson DV, Heito MV (2001) Knowledge for inclusive development: the challenge of globally integrated learning and implications for science and technology policy. Technological Forecasting and Social Change, pp: 1-29.

40. Alkire S (2002) Dimensions of human development. World Development pp: 181-205.

41. Jahan R, Mumtaz S (1996) The elusive agenda: Mainstreaming Women in Development. The Pakistan Development Review, pp: 825-834.

42. Weiss TG (2010) Governance, good governance, and global governance: conceptual and actual challenges. Third World Quarterly, pp: 795-814.

43. Graham J, Amos B, Plumptre T (2003) Principles for good governance in the 21st Century. Ottawa, Ontario: Institute of Governance.

44. Ciborra C, Navarra, DD (2010) Good governance, development theory, and aid policy: risks and challenges of e-government in Jordan. Information Technology for Development, pp: 141-159.

45. Santiso C (2001) World Bank and Good Governance: good governance and aid effectiveness, the world bank and conditionality. Geo Public Policy Review 7: 1-137.

46. Erickson-Davis M (2017) Police clash with protesters marching against power plant in Bangladesh. Mongabay.

47. Islam S, Tusher HJ (2011) Govt Eyes Arial Beel, 3 other Sites. The Daily Star.

48. Ray A (2011) Bangladesh: proposed international airport stumbles over environment controversy. The Global Voice.

49. Morshed A (2011) Arial Beel's Versailles moment. BDNews 24.com.

50. Ali H (2017) Personal interview.

51. Begum M (2017) Personal interview.

52. Berger M, Barkat A (2007) Radical Islam and development aid in Bangladesh. The Hague: Netherland Institute for International Relations.

53. Börzel TA, Yasemin P, Andreas S (2008) Good governance in the European Union. Berlin: Berlin Working Paper on European Integration.

54. Grzeszczak R (2015) The concept and practice of good governance in the European Union. International Journal of Social, Behavioral, Educational, Economic, Business and Industrial Engineering, 9.

55. Malinowski B (1994) The problem of meaning in primitive languages. Language and literacy in social practice: A reader, pp: 1-10.

56. Ray AK (2008) Measurement of social development: an international comparison. Social Indicators Research, pp: 1-46.

57. United Nations Development Program (1990) Human development report. Oxford University Press, New York. 